\title{
LILRB1 wt Allele
}

National Cancer Institute

\section{Source}

National Cancer Institute. LILRB1 wt Allele. NCI Thesaurus. Code C124241.

Human LILRB1 wild-type allele is located in the vicinity of 19q13.4 and is approximately $127 \mathrm{~kb}$ in length. This allele, which encodes leukocyte immunog lobulin-like receptor subfamily B member 1 protein, plays a role in the inhibition of immune responses. 